\title{
THE DUTCH REFORMED CHURCH AND THE TRUTH AND RECONCILIATION COMMISSION
}

\author{
Piet Meiring \\ Department of Theology and \\ former Commissioner of the Truth and Reconciliation Commission \\ University of Pretoria
}

\begin{abstract}
For the Nederduitse Gereformeerde Kerk [Dutch Reformed Church (DRC)] in South Africa, the church that supported the policy of apartheid for many years, engaging the South African Truth and Reconciliation Commission (TRC) was a painful and in the end also a liberating experience. In his article Piet Meiring, who served on the $T R C$, chronicles the dialogue between the TRC and the DRC, leading to the events of the the Faith Community Hearing in November 1997 when the DRC, together with all the other faith communities in South Africa, appared before the TRC to explain its role during the apartheid years, as well as its commitment towards future reconciliation. Meiring discusses the expectations as well as disappointments that surfaced during the truth and reconciliation process, with regard to the Dutch Reformed Church, offering a number of comments on viewpoints adopted and actions taken by the church.
\end{abstract}

\section{Introduction: A day to remember}

In the annals of the Nederduitse Gereformeerde Kerk (Dutch Reformed Church, DRC), the day will always be remembered: Wednesday, November 19, 1997. It was just after the Truth and Reconciliation Commission had resumed its session after lunch, when the moderator, the Rev Freek Swanepoel, took his place on the podium. Next to him appeared Dr Willie Botha, ecumenical officer of the church. Throughout the week one church after the other - also leaders from the other faith communities, the Muslim, the Hindu, Jewish, Buddhist, Traditional African communities - were invited to address the TRC, to explain their role during the apartheid years in South Africa (TRC Report, IV, 59-92). Now the time had come for the DRC, the church which had not only happily lived with apartheid and provided from its membership numerous politicians, civil servants, as well as army and police officers, the enforcers of apartheid, but the church who over many years developed a theological argument for apartheid, to face the TRC, and the nation (Boraine, 181, cf Mandela, 156).

"We are very grateful that you are here today", Desmond Tutu, the TRC chairperson, welcomed the two clergymen. "We would have been disappointed if this has not been the case" (Meiring, 277). Freek Swanepoel started his address in English, but soon switched to Afrikaans:

"I am thankful to the TRC for the invitation to take part in the faith community hearing... I am also thankful to the General Synodical Commission of the DRC for sending me to witness to the TRC and all the people of this country that this church is called to reconciliation between all people." Disarmingly honest Swanepoel continued: "Die vraag kan gevra word of ek namens die hele NG Kerk praat. Dit kan en mag ek nie sê nie." There were two groups of people in the church, he explained, those who supported the DRC's appearance before the TRC, and those who opposed it. "I believe, however, that those who 
are positive, who want to rise to the challenge of reconciliation, are in the majority" (Meiring, 278).

Freek Swanepoel had it right. Behind his words were two long years of debating and agonizing the question: should or shouldn't the DRC work with the TRC? From the start the church was ambivalent in its relationship with the Truth Commission. I tried to chronicle the main events in the life of the TRC, also giving attention to the dealings between the Nederduitse Greformerde Kerk and the Commission. Allow me to quote some of these.

\section{A Chronicle of events}

\section{March 1996}

Two weeks after the TRC opened its doors, the moderature of the DRC visited the Truth Commission's offices in Cape Town to discuss the role the Church may be able to play in the TRC process. There was much to discuss, Die Kerkbode (official newspaper of the DRC, 9-10 February 1996) reported. Indeed, already in December 1995 when the mandate of the TRC was debated in public the DRC promised its support as well as its prayers, asking the TRC to act impartially, being fair to all parties who were to appear before the commission. The DRC went beyond that, naming seven possible candidates from its ranks to serve on the TRC. None of them made the grade, which rankled a bit. The fact that one DRC theologian - moderator of one of the regional synods - eventually was invited to serve on the commission provided some consolation.

On the agenda, too, was the fact that during February 1996 a group of 46 ministers and theologians from the ranks of the DRC pledged their support to the TRC. The DRC has on many occasions confessed its guilt of apartheid, the group stated in an open letter: "We are now facing the test to convert these confessions into actions... We trust that the Church will have the courage and humility to accept this difficult task. In this we dare not let the members of the Church down" (Die Kerkbode, 9-10 February 1996).

At this stage, the relationship between the TRC and DRC was cordial. Much was at stake, Tutu and Swanepoel - and their colleagues - agreed. After the meeting Frits Gaum commentated in his editorial column: "It will be a traumatic time for all of us, but if undertaken correctly, it can also be a time of purging, a catharsis which can eventually heal our country" (Die Kerkbode, 9-10 February 1996).

\section{July 1996}

Four months had passed. The TRC was in the middle of its victim's hearings. The past days the nation was invited - night after night in the special TRC slot after the 8 o'clock television news - to become part of the Soweto hearings. The stories of the many victims, the harrowing details of what happened to them, the report on the children's uprising of June 16 1976, the fate of men and women - among them also of Dr Edelstein, the Jewish doctor who was stoned to death by an angry mob, shook the nation. Not only among the blacks, but also among whites tension was rising.

The moderature of the Western Cape Synod met with TRC officials. They were concerned about the fairness of the process: "You will have to make a better effort of assuring and convincing people that the TRC will not degenerate into a witch hunt". The TRC was equally concerned. Will the DRC fulfil its role to lead its members on the difficult road of confession and reconciliation? (Meiring, 61). 


\section{October 1996}

Was the DRC indeed willing to take the risk, to lead its members along this road? A heartening answer was waiting at the Paarl hearing, on 15 October 1996. On the agenda that day were old, half forgotten testimonies on the Poqo uprising. Mothers of young men who died in the border war - on both sides of the political divide - shared their tears with the audience.

And then two DRC clergymen appeared, one an aging professor, the other a young minister, with a comprehensive statement by the Ring (the Presbytery) of the DRC in Stellenbosch. They presented a moving document telling the story of Stellenbosch, in many instances the cradle of Afrikanerdom, as well as of the DRC, of how Stellenbosch treated its people, how whites failed to see the pain in the eyes of their fellow Christians, of how the theology of apartheid found its roots in their town. Bethul Müller's testimony, as well as that of Jan Marais, visibly moved the audience also Dr Tutu, "It is remarkable that of all churches, it is the NG Kerk in particular, who comes to the Truth Commission first... I hope many of the churches will follow its example" (Meiring, 81).

\section{October 1996}

Not everyone in the DRC was as happy as Tutu seemed to be with the Stellenbosch submission. "Daar gaan die Stellenbossers al weer!" it was said. Do we really have to apologise, to Tutu and his colleagues? What about the good intention of apartheid? Many joined the fray - in the media as well as in local discussions.

The General Synodical Commission was equally - and deeply - divided. Should the DRC follow the Stellenbosch lead? With a majority of three votes, the General Synodical Commission decided not to submit a statement, not to make a confession to the TRC. "Our members will not take it. It will create far too much disturbance", was the feeling of the majority.

A few days later the Western Cape moderature decided to go ahead with their statement, if needs be, alone. Christo Alheit (secretary of the moderature) told the press: "The Western Cape moderature believes that the TRC offers a unique opportunity to testify, that must be utilized" (Meiring, 94ff, cf Notule, Sinode van die Wes- en Suid-Kaapland, 1997, 27ff).

\section{February 1997}

At the annual opening of the Theological Faculty, Stellenbosch, the role of the DRC in the TRC process was once again on the agenda. Old and New Testament scholars spoke about guilt, forgiveness and reconciliation in the Bible. I had to present the case of the TRC. Antjie Krog, reporter for the South African Broadcasting Corporation went along, to record the event (Krog, pp 163f). Much was discussed: the question of (Afrikaner) guilt, the reaction of whites against the TRC process, how to enlist the support of the church community in the process of reconciliation. At the back of everybody's mind was the question: should the DRC make a submission to the TRC? The day, however, was carried by emeritus professor Dawid de Villiers. "We can no longer afford to play games," Heilige Dawid warned." The NG Kerk has an enormous responsibility to guide our people... I am an old man, my time is short. But I, who lived in the paradise time of apartheid implore you... Do something! Put the history of my church before the feet of the Truth Commission, before it is too late, before the new millennium comes!" (Meiring, 115, cf Krog, 164).

A similar - and even more serious - voice came from the other side of the Hex River, from no other than the aging Beyers Naude. Oom Bey, together with Nico Smith and a 
number of colleagues, published a moving open confession of their guilt. Most South Africans were amazed. Oom Bey of all people - the man who suffered so much because of his fight against apartheid! "I have not done enough," Oom Bey said to the press. How is it possible that our preaching was so ineffective, that our actions were so timid, that we did so little to ease the pain of the victims, to confront the rulers of the country, the exponents of the ideology of apartheid?" (Meiring, 115ff, cf An Open Letter to Pastors of All Churches in South Africa, Submission to the TRC Faith Community Hearing, 247-248).

A substantial number of DRC theologians and pastors co-signed Oom Bey's confession - together with colleagues from other denominations, who identified with it. But not all of them! Reaction from the side of the three Afrikaans Susterkerke ("sister churches") was swift. Another eminent emeritus theologian, Professor Bouke Spoelstra from the Gereformeerde Kerk retorted in his column in Beeld "The TRC makes me think of the witch hunts and the inquisition of the Middle Ages where Dominian investigators tried witches and heretics, and handed them over to be punished or to be burned to death". Tutu and vice-chair Boraine, indeed the TRC itself, was according to him incompetent and unequipped to lead the country towards truth and reconciliation! (Meiring, 158).

\section{7-19 November 1997}

During the months that followed - indeed throughout the year 1997 - the TRC continued with its work. Having finished with its victim's hearings, attention was given to institutional hearings, where many of the main institutions of South African society, were asked to appear before the TRC: Political parties, the medical fraternity, the lawyers and judges, the business community, academic leaders, the media, correctional services, women's groups, to name but a few. High ranking individuals, too, appeared - among them Winnie Madikizela-Mandela (TRC Report IV, 18ff).

In November 1997, at the very last public hearing of Human Rights Violations Commission, the Faith Communities of South Africa, were given their opportunity to state their case, to help the TRC come to an understanding of the apartheid past - and of the faith committee's role in either fighting against, or upholding, apartheid in South Africa.

Most of the churches were immediately willing to come to the hearing. The Muslim, Hindu, Jewish, as well as the other communities decided to follow suit. But in the circle of the Afrikaans Churches there was grave hesitation - even opposition - to the idea. The Gereformeerde Kerk officially decided not to make a statement. The Hervormde Kerk chose not to respond to the invitation. And the Nederduitse Gereformeerde Kerk was once again in turmoil (Meiring, 266f).

Something has to be said, everybody seemed to agree. But what? And to whom? In the end the General Synodical Commission asked Frits Gaum to draft a lengthy statement for the edification of the church's own members on The Story of the DRC's Journey with Apartheid - which in due course was adopted as the official statement of the Church on its role in the past. It was not addressed at the TRC - but it was noted, if the TRC wanted to use it, they would be free to do so!

The debate continued, however. It came as a huge relief, only days before the Faith Community Hearing was due to start, that the General Synodical Commission - significantly, at a meeting in Rustenburg - unanimously decided to send Freek Swanepoel to the TRC, to represent the DRC, to make a submission to the Commission

Which brings me back to November 19 1997, the afternoon session. Freek Swanepoel was not the only person to speak from the ranks of the so-called DRC Family. The Rev James Buys spoke eloquently and comprehensively on the history and the pain of the so- 
called "daughter churches", in their relationship with the "mother church" who often in their experience turned her back on them. He told a hushed audience of the double burden they had to carry when their black compatriots blamed them for the sins of the mother church, for being co-responsible for the suffering of the people. And when the younger church found its voice and poured its heart into the Belhar Confession, the mother church answered with harsh criticism (cf. Submission, 137ff). Other members of the DRC Family also took to the podium: representatives of the Belydende Kring (cf Submission 148ff) as well as Nico Smith who tabled Beyers Naudé's open letter (Submission, 247ff).

How sad, I thought at the time, that the DRC Family had still not succeeded in reuniting into one church, the one NG Kerk they used to be. One of the highlights of the hearings was when two representatives of the Apostolic Faith Mission which used to be as deeply divided into white and black sections, walked to the podium together. Their story of how the two sections of the AFM reached out to one another, how they became one, moved the audience. Reconciliation does happen, Frank Chikane and Izak Burger told the TRC (AFM Submission, 119ff) The audience responded with a hymn of praise. What a testimony it would have been of the gospel of peace, of the fact that the DRC has really taken leave of apartheid in all its consequences if Freek Swanepoel and James Buys and the others had approached the TRC together. But, sadly, the opportunity was lost. It did not happen.

\section{Expectations and disappointments}

What was the outcome of the relationship between the TRC and DRC?

There were, on the one hand, high expectations from both sides. President Mandela visited the DRC General Synod in 1994, expressing his sincere hope that the DRC would contribute to the process of nation building and reconciliation (Journey with Apartheid, $\mathrm{p}$ 29). Desmond Tutu, and the TRC, had equally high hopes of the role of the DRC in finding the truth of what happened in apartheid South Africa, of understanding the context, of building a bridge from the pain of the past for a new future of understanding and reconciliation, of guiding its members on the road of peace and prosperity. Some of these hopes were realized - and I will refer to that just now.

But, on the other hand, there was also disappointment with whites in general, Afrikaners and English - and the DRC in particular - for remaining aloof, for not using the opportunities given to them, for not entering into the spirit of truth and reconciliation. Too often the conspicuous absence of whites at the hearings were painful and confusing to black South Africans. Also the heated debates in committee rooms and in the media on whether the church should or should not co-operate with the TRC did not escape the Commission's notice.

What were the reasons for this? May I, in conclusion, offer four brief remarks in this regard?

3.1 The DRC evidently found it difficult to really and wholeheartedly confront its apartheid past. The DRC has - as was stated in the Open Letter of the 46 theologians made all the right statements, has used all the expected terms in its confession of apartheid, to the point of declaring apartheid, and the church's defence of the system "a sin and a heresy" (General Synod 1998). But to "pass the test to convert these confessions into actions" was quite another matter. The Stellenbosch Ring, Beyers Naudé and his colleagues, some church leaders, did set an example - but for many in the pew it was a hard act to follow. It was not that difficult, it seems, to erase apartheid 
from the statute books, from the official policy documents of the church - but to get it out of our hearts, was quite another matter! It may take generations to do that.

3.2 The DRC found it equally difficult to provide pastoral support - not only for perpetrators and victims who approached the TRC, but for millions of its membership who were traumatized by the process, by being confronted - albeit reluctantly - by the results of the policy they voted for, and profitted from. I personally agonized about the absence of Afrikaners, DRC members, at TRC hearings - when it, one day, dawned upon me: What the American therapist Elizabeth Kübler-Ross (10ff) wrote about individual suffering, and on how to councel men and women caught up in existential crises, also applies to communities, in this case to white South Africans confronted by the atrocities of the past, and by their direct or indirect complicity. Denial, anger, rationalization, deep despair - those were also the stages we, white South Africans, experienced. If only the church and its ministers realized that, if only the pastors were able to recognize the stage their flock found themselves in, the DRC would have been able to guide them to the mature stage of acceptance, and peace, reaching out towards reconciliation.

3.3 Speaking of which: My third remark is that reconciliation, too, did not come easily to the DRC. Everyone wanted it, of course. But reconciliation seemed elusive. It was difficult to define, it was a fragile flower, something that had to be planted and cared for, often at great cost. Reconciliation is a gift from God, true. But reconciliation also asks for human participation. Reconciliation is not possible without the quest for truth, even finding the most painful of truth. For reconciliation is not synonymous with amnesia. It is built on truth, the truth that eventually sets one free.

Moreover, reconciliation and justice are two sides of the same coin. To speak for reconciliation means to speak out against injustice, missing issues of affluence and poverty, of unemployment and Aids, discussing highly emotive issues of land, of affirmative action, of restorative justice and reparation. Not everyone is overly enthusiastic about these issues - about the way these issues were put by the TRC on the national agenda, as well as on the role that the churches were expected to fulfil in this regard (Jefferey,1ff; Roodt, p 120). But the issues are ignored at our peril.

Freek Swanepoel indeed touched on some of these in his submission, deeply regretting the actions or neglect of the DRC in this regard, committing himself and his Church to future action (DRC Submission, 158).

But the question remains: Are we willing to pay the price of reconciliation? One night in my car, driving from the umpteenth Sunday service trying to urge the congregation on the way of truth and reconciliation, a friend of mine remarked: "Piet, of course we want reconciliation. Who in his right mind does not want reconciliation in South Africa? But then, please, at the lowest possible price. Uitverkopingsprys!" I often think that what we need in South Africa is a rewriting of Dietrich Bonhoeffer's theology - not a Theology of Costly Grace, but a theology of Costly Reconciliation (Bonhoeffer, 1963).

3.4 My last remark has to be a positive one. From time to time the DRC - synods, presbyteries, theologians, congregations, members - did rise to the challenge of truth and reconciliation. Some of the events I chronicled attest to that. It sometimes happened in the most unexpected of places. It happened in the Paarl 
Town Hall where two DRC ministers, one a graying emeritus professor, the other a young parish minister, asked for forgiveness from the people of the Boland (Meiring, 81). It happened in a NG kerksaal (church hall) in Port Elizabeth where a perpetrator and the family of his victim met and were reconciled (Meiring, 123ff). It happened, too, on a Sunday morning in Lynnwood Pretoria where an ex-army chaplain found himself in Tutu's embrace, in the pulpit, the congregation bursting into applause (Meiring, 362ff). Tutu's own account of the Lynnwood experience provides fascinating reading. "God has done some strange things in the history of our land", he concludes. "That was one of the more unusual. That it should have happened in a Pretoria suburb in a Dutch Reformed Church made it particularly poignant" (Tutu, p 147). Some of the experiences were carried beyond the TRC years. For three months, in the last quarter of 2001 (the DRC's "Year of Hope") congregants in many churches were trained in the process of reconciliation, working from a meticulously prepared manual (Op pad na versoening), prepared by the church for its members.

\section{Hope for South Africa - and for the DRC}

Maybe, there is hope for the DRC. Tutu, in his closing remarks, after Rev Swanepoel's submission seemed to think so:

"I want to thank the Lord for what happened today. That you came to say that you are sorry was truly wonderful! ... I always say: Once an Afrikaner has seen the light, he does not turn back...We have seen how over the years the once rejected church has returned, confessed its guilt... I feel like telling the devil: 'Just you watch it. The NG Kerk is coming!" (Meiring, 279).

After his gracious words, Tutu requested Freek Swanepoel to pray. Then he got up and embraced the moderator of the DRC.

Almost a year later, in October 1998, Tutu handed the final report of the TRC to President Mandela, in Pretoria. His final words still ring in my ears, as the prayer lives in my heart that in some way the DRC may be part of Tutu's dream:

"We have been wounded but we are being healed. It is possible even with our past of suffering, anguish, alienation and violence, to become one people, reconciled, healed, caring, compassionate, and ready to share as we put our past behind us to stride into the glorious future God holds before us as the Rainbow People of God" (Meiring, 379). 


\section{BIBLIOGRAPHY}

Bonhoeffer, Dietrich 1963. The cost of discipleship, transl. RH Fuller, New York Macmillan.

Boraine, Alex 2000. A country unmasked. Oxford: Oxford University Press.

Jeffery, Anthea 1999. The truth about the Truth Commission. Johannesurg: Institute for Race Relations.

Krog, Antjie 1998. Country of my skull. Johannesburg: Random House.

Kübler-Ross, Elizabeth 1973. On death and dying. London etc: Tavistock.

Mandela, Nelson 1994. Long walk to freedom. Randburg: Macdonal Purnell.

Meiring, Piet 1999. A Chronicle of the Truth Commission. Vanderbijlpark: Carpe Diem.

Nederduitse Gereformeerde Kerk (Sinode Wes- en Suid-Kaap) 1997: Voorlegging aan die Waarheids- en Versoeningskommissie, Handelinge 1997 (27ff).

Nederduitse Gereformeerde Kerk (Algemene Sinode) 1998. Handelinge. Pretoria: NG Kerk.

Nederduitse Gereformeerde Kerk 1997. The story of the DRC's journey with Apartheid (1960-1994). Pretoria: DRC.

Roodt, Dan 2000. Om die Waarheidskommissie te vergeet. Dainfern: Praag.

Truth and Reconciliation Commission 1997. Reports tabled at the TRC Faith Community Hearing (pages refer to the hearing's official Agenda):

1. Apostolic Faith Mission. Submission (132-136).

2. Belydende Kring. Submission (148-153).

3. Nederduitse Gereformeerde Kerk (DRC). Submission (152-158).

4. Ring van Stellenbosch (DRC). Submission (159-161).

5. Uniting Reformed Church in Southern Africa. Submission (124-146).

6. Beyers Naudé et al. An open letter to pastors of all churches in South Africa (247-248).

Truth and Reconciliation Commission 1998. Final Report Vol 1-5. Cape Town: TRC.

Tutu, Desmond 1999. No future without forgiveness. London: Rider. 